\title{
Wybrane metody hodowlane wykorzystywane przez DANKO Hodowla Roślin Sp. z 0.0. oraz oczekiwania spółki wobec polskich naukowców
}

\author{
Selected breeding methods used by DANKO Hodowla Roślin Sp. z o.o. and the \\ company's expectations towards Polish scientists
}

\author{
Jarosław Haremza \\ DANKO Hodowla Roślin Sp. z o.o. \\ ZHR Oddział Choryń \\ $\triangle$ e-mai: jaroslaw.haremza@danko.pl
}

\begin{abstract}
W pracy syntetycznie przedstawiono działalność hodowlaną spółki DANKO Hodowla Roślin Sp. z o. o. Wskazano zakres prowadzonych prac jak i możliwości nawiązania współpracy z nauką. przedstawiono metody i techniki stosowane przez spółkę w pracach hodowlanych.
\end{abstract}

Slowa kluczowe: DANKO HR, hodowla, zboża

The work presents the breeding activity of DANKO Hodowla Roślin Sp. z o. o. The scope of work was indicated as well as opportunities to establish cooperation with science. Methods and techniques used by the company in breeding are presented.

Key words: DANKO HR, breeding, cereals

DANKO Hodowla Roślin to spółka z ograniczoną odpowiedzialnością, której właścicielem jest zgromadzenie wspólników, czyli Krajowy Ośrodek Wsparcia Rolnictwa (KOWR). Oprócz hodowli roślin, firma zajmuję się, także nasiennictwem oraz hodowlą bydła mlecznego, a od niedawna hodowlą buhajów. DANKO posiada 5 Zakładów Hodowli Roślin oraz filie Sobiejuchy podlegającą pod Zakład Hodowli Roślin oddział Choryń. Spółka gospodaruje na prawie 6300 hektarów, z czego corocznie na hodowlę przeznaczonych jest prawie 200 hektarów, co daje około 330 tysięcy poletek hodowlanych.

W spółce DANKO prowadzona jest hodowla twórcza 12 gatunków roślin uprawnych (w tym 9 gatunków zbóż) oraz hodowla zachowawcza 3 gatunków roślin bobowatych i 6 gatunków traw.

Program pszenicy ozimej jest jednym z największych i najważniejszych programów w firmie DANKO, dlatego hodowla tego gatunku prowadzona jest aż w czterech oddziałach firmy: w Choryni, w Laskach, w Dębinie i w Modzurowie. Aktualnie DANKO posiada w sprzedaży 18 odmian pszenicy ozimej: 9 autorskich i 9 odmian zagranicznych, których jest reprezentantem na rynek polski. Dodatkowo w Choryni prowadzony jest program hodowli pszenicy jarej. Firma bierze udział w 14 projektach obejmujących badania podstawowe na rzecz Postępu Biologicznego w Produkcji Roślinnej finansowanych przez Ministerstwo
Rolnictwa i Rozwoju Wsi, dotyczących pszenicy. Najmłodszym programem w firmie jest program pszenicy mieszańcowej. DANKO Hodowla Roślin wraz z innymi europejskimi firmami hodowlanymi uczestniczy w międzynarodowym przedsięwzięciu pod nazwą Hyballiance, którego celem jest wyhodowanie odmiany mieszańcowej pszenicy ozimej. W programie wykorzystywane są min. nowoczesne metody hodowlane, takie jak prowadzenie selekcji wspomaganej markerami molekularnymi.

Drugim największym programem hodowlanym w spółce jest program hodowli pszenżyta ozimego, który również prowadzony jest w 4 oddziałach (Choryń, Laski, Dębina, Szelejewo). W ofercie sprzedażowej firma posiada 20 odmian autorskich. W oddziale Laski, oprócz klasycznej hodowli, prowadzona jest także hodowla mieszańcowa pszenżyta ozimego, a w Choryni prowadzony jest program hodowli pszenżyta jarego. Firma posiada w ofercie sprzedażowej 6 odmian pszenżyta jarego. DANKO bierze udział w 10 tematach badawczych w ramach Postępu Biologicznego, związanych z pszenżytem.

$\mathrm{W}$ firmie DANKO prowadzone są 2 programy hodowlane żyta ozimego: populacyjnego (Choryń i Laski) oraz mieszańcowego (Choryń, Sobiejuchy i Laski). W sprzedaży DANKO posiada 8 odmian populacyjnych i 2 odmiany mieszańcowe. Firma 
uczestniczy w 8 tematach z Postępu Biologicznego.

Hodowla jęczmienia ozimego prowadzona jest $\mathrm{w}$ Szelejewie. Aktualnie firma nie posiada autorskich odmian, jednak jest liderem na rynku nasiennym, ponieważ reprezentuje 6 odmian firm zagranicznych.

Poza jęczmieniem ozimym DANKO prowadzi również hodowlę jęczmienia jarego. Jest to stosunkowo młody program prowadzony w Kopaszewie (oddział Choryń) oraz w Modzurowie. Firma posiada w ofercie 19 odmian, $\mathrm{z}$ czego jedną odmianę autorską. DANKO bierze udział w 3 tematach badawczych z Postępu Biologicznego obejmujących tematykę jęczmienia ozimego i w 4 tematach badawczych z zakresu jęczmienia jarego.

W Kopaszewie prowadzony jest równolegle program owsa jarego. Obecnie firma posiada 10 odmian w sprzedaży. Bierze także udział w 6 projektach z Postępu Biologicznego.

Oprócz zbóż, w DANKO (oddział Szelejewo) prowadzona jest hodowla roślin bobowatych i traw. Firma posiada program hodowli twórczej grochu siewnego, a od niedawna uruchomiony został program hodowlany soi. DANKO ma już pierwsze sukcesy w tym gatunku w postaci autorskiej odmiany o nazwie Erica, która została zarejestrowanej w 2017 roku. Spółka w ofercie posiada także 5 odmian grochu. Prowadzona jest hodowla zachowawcza bobiku, wyki i lucerny, a w sprzedaży znajduje się łącznie 9 odmian tych gatunków. Firma bierze udział w dwóch tematach badawczych z Postępu Biologicznego dotyczących soi oraz w Programie Białkowym finansowanym również przez MRiRW.

W przypadku traw hodowla twórcza prowadzona jest tylko dla życicy wielokwiatowej, natomiast w pozostałych gatunkach (życica trwała, Festulolium, tymotka łąkowa, mietlica biaława, kostrzewa trzcinowa, kostrzewa murawowa) hodowla twórcza jest stopniowo wygaszana. Równocześnie prowadzona jest hodowla zachowawcza tych gatunków. Firma posiada w sprzedaży 5 odmian życicy wielokwiatowej oraz łącznie 17 odmian pozostałych gatunków traw. DANKO bierze udział w 3 projektach z Postępu Biologicznego dotyczących traw.

Ponieważ na rynku firm hodowlanych jest coraz większa konkurencja, DANKO Hodowla Roślin do programów hodowlanych prowadzonych w sposób klasyczny, wprowadza innowacyjne i nowoczesne techniki. Jedną $\mathrm{z}$ nich jest metoda kultur in vitro, a dokładnie otrzymywanie roślin podwojonych haploidów. Metoda pozwala skrócić cykl hodowli o 2-3 lata, ponieważ na jej drodze otrzymuje się rośliny homozygotyczne w czasie krótszym niż jest to możliwe metodami tradycyjnymi. Prace nad otrzymaniem roślin DH prowadzone są w Centrum Biotechnologii DanLab, które zlokalizowane jest w Kopaszewie oraz w laboratorium kultur in vitro $\mathrm{w}$ Szelejewie. Metodami stosowanymi przy otrzymywaniu roślin DH są: androgeneza, metoda izolowanych mikrospor oraz krzyżowania oddalone $\mathrm{z}$ kukurydzą. Oprócz tego do przyspieszenia cyklu hodowli pszenicy i jęczmienia stosuje się metodę niedojrzałych zarodków oraz metodę SSD (pojedynczych nasion). Gwarantuje to szybsze uzyskanie roślin homozygotycznych $\mathrm{w}$ porównaniu do tradycyjnej metody rodowodowej.

Jedną $\mathrm{z}$ najnowocześniejszych metod jest hodowla molekularna polegająca na prowadzeniu selekcji na podstawie polimorfizmu markera molekularnego silnie sprzężonego z loc us cechy użytkowej - MAS (z ang. marker assisted selection). W związku $\mathrm{z}$ czym selekcja prowadzona jest, nie jak $\mathrm{W}$ przypadku tradycyjnej hodowli na podstawie fenotypu, tylko na podstawie genotypu roślin. Fenotyp zależny jest od genotypu oraz podlega modyfikacjom środowiskowym, które mogą maskować zróżnicowanie genetyczne osobników. Stąd też wyłania się potrzeba wdrażania do hodowli roślin metod, które w bardziej bezpośredni sposób pozwolą na określenie genotypu ocenianych pojedynków. Obecnie coraz częściej selekcja fenotypowa wspierana jest różnymi analizami molekularnymi, jak również same techniki molekularne są bardziej zaawansowane. Dąży się do tego, żeby $\mathrm{w}$ trakcie jednej analizy ocenić $\mathrm{u}$ jak największej liczby osobników wiele cech równocześnie, przy użyciu całej dostępnej puli markerów molekularnych. Analizy tego typu obejmują selekcję genomową, która dotyczy zarówno cech jakościowych jak i ilościowych. Wdrożenie selekcji genomowej daje szansę na bardzo trafny wybór pojedynków już w fazie siewki pod kątem wielu cech jednocześnie. Do tej pory firma DANKO zlecała analizy molekularne firmą zewnętrznym, ale w najbliższym czasie planuje otworzenie własnego laboratorium analiz molekularnych.

Od 2016 roku spółka bierze udział w projekcie POIR obejmującym działania z zakresu hodowli twórczej nowoczesnych 
odmian. Poza projektami krajowymi firma uczestniczy również w projektach europejskich.

Pomimo prowadzenia własnych prac badawczych, DANKO Hodowla Roślin jest otwarta na współpracę $\mathrm{z}$ polskimi jednostkami naukowymi. Wspólnie chcielibyśmy rozwiązać takie problemy, jak: optymalizacja procesów otrzymywania roślin DH; nowe źródła genów odporności na choroby, suszę oraz wymarzanie; selekcja wspomagana markerami; identyfikacja markeru do genu przywracania płodności w systemie cms Pampa (Rfp1); wzbogacanie puli genetycznej poprzez krzyżowania oddalone; nowoczesne metody biotechnologiczne wykorzystywane w hodowli roślin.

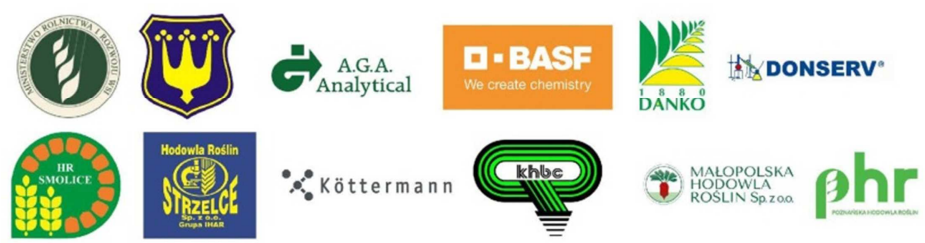


